sounds like I can't do my job... yet others in the artistic community don't expect me to talk the talk-they still welcome me with open arms. Talk warmly about what we in the programme are hoping for, offer their assistance and brainstorm over a cuppa. I don't have a clue what the best materials are for printing large prints on, or how much you should expect to pay for video editing, or how to organise an exhibition but I do know how to organise, write grants and talk to mums. And despite my lack of artistic skills, these artists willingly sit down to help with my shoes and welcome me into their world.

So as we get tiredly to the Friday of another week, the director of the art gallery is planning a visit next week, and I hear myself asking 'why am I doing this?' I have to give myself a nudge and reminder that this programme is about improving outcomes for Aboriginal mothers and their infants. This programme is about creating opportunities for learning that these mothers seem to miss otherwise. And as always, my commitment is to the final outcomes of these tiny innocent babies, so with this, despite the poor fit, I will be wearing someone else's shoes for a time to come.

Acknowledgements The author would like to thank the team of the Gomeroi gaaynggal programme (Loretta Weatherall, Patty Mackay, Aunty Pearl Slater, Andrea Bruno and Roger Smith) who have been wonderfully supportive. In addition, special thanks must be extended to Catherine Oddie, Manager

ArtsHealth-Research Development, Faculty of Education and the Arts, University of Newcastle.

Funding Thyne Reid Trust.

Competing interests None.

Provenance and peer review Not commissioned; externally peer reviewed.

\title{
Miscellanea
}

\section{Prom night number two: code blue}

\author{
I never expected I'd go \\ in a gown. \\ But there I was, sixty-five years later, \\ in one that ties up twice \\ in the back. Baby blue. \\ My first prom I wore a corset. \\ My date who became a doctor, \\ said, "Goodnight, it's been fun," \\ when he dropped me off at home, \\ after a night of vodka and heavy petting. \\ I married someone else, \\ and never saw him again.
}

Take two. This time I went solo.

I didn't spend long

perfecting that waxy yellow hospital gleam

in front of the mirror. I rearranged the flowers by my bed.

My intractable skin

sagged stubbornly off my jawbone.

The nurses screamed code blue,

The handsome young doctors ran over.

I pretended that this time, my vanity didn't

get the better of me.

When it was done, I was left alone

with only a few wayward flyaways,

my lipstick smudged just as much as you'd expect

after a night of chemical intoxication and heartbreak.

\section{Tamar S Rubin}

Correspondence to Ms Tamar S Rubin, University of Toronto, Toronto, Canada; tamar.rubin@utoronto.ca

Competing interests None.

Provenance and peer review Not commissioned; not externally peer reviewed.

Accepted 9 March 2010

J Med Ethics; Medical Humanities 2010;36:42. doi:10.1136/jmh.2010.004309 